\title{
Fertility control in laboratory rats and mice after feeding with the antigestagen RU486
}

\author{
Y. Gao and R. V. Short \\ Department of Physiology, Monash University, Melbourne, Victoria 3168, Australia
}

\begin{abstract}
The intermittent use of an antigestagen could prove to be a very effective way of controlling the fertility of rats and mice in the wild. This concept was tested by giving paraffin wax blocks containing cereal grains and the antigestagen Mifepristone, RU486 (150 $\mathrm{mg} \mathrm{kg}^{-1}$ block) to male and female laboratory rats and mice in a series of free-choice feeding experiments. There was no significant difference in the consumption of blocks with or without RU486, showing that it was completely palatable to rats and mice, and no aversion developed following refeeding. The average consumption of RU486 by rats was $11 \mathrm{mg} \mathrm{kg}^{-1}$ day $^{-1}$; mice consumed $37 \mathrm{mg} \mathrm{kg}^{-1}$ day $^{-1}$. All the females showed persistent oestrous vaginal smears throughout the treatment. When male and female rats and mice were given continuous access to treated paraffin blocks for 30 days, no conceptions occurred. At the end of this time, there was a significant increase in ovarian weight in the treated rats and mice, but no difference in testicular weight. Treated blocks were given to rats for 3 days every 21 days for a total of 115 days. Four dead litters were produced following the first antigestagen treatment on day 21 , but no more litters were produced and no treated rats were pregnant when autopsied on day 115. Mice were initially treated for 3 days every 21 days, but some animals continued to produce live young on this schedule. The treatment period was therefore reduced to 3 days every 18 days and no more litters were produced and none of the treated females was pregnant at autopsy. The antigestagen RU486 shows considerable promise as a chemosterilant for the control of fertility in female rats and mice. Intermittent administration every 18 days (mice) or 21 days (rats) in free-choice feeding trials completely inhibited reproduction.
\end{abstract}

Introduction

RU486, one of a group of antigestagens, has been extensively studied in laboratory animals and in women for its abortifacient properties (Kovacs et al., 1984; Neef et al., 1984; Philibert et al., 1985; Beier et al., 1986; Chwalisz and Elger, 1986; Van Look and Bygdeman, 1989; Ulmann et al., 1990). It has also been shown that daily administration at low dosages inhibits ovulation in monkeys and women (Croxatto et al., 1993). We proposed that antigestagens might therefore prove useful as chemosterilants for the control of animal populations (Gao and Short, 1993a). Theoretically, it would only be necessary to administer the compound intermittently, at an interval determined by the duration of gestation of the species in question, to inhibit reproduction. This would make it ideally suited for use in seasonally monoestrous species like foxes, where it would only need to be administered once a year ( $\mathrm{Gao}$ and Short, 1993a).

Since RU486 is known to be a potent antigestagen in rats and mice, we investigated whether it was palatable to rats and mice, and whether an intermittent dosage regimen could be developed that would completely inhibit reproduction.

\section{Materials and Methods}

\section{Animals}

Sexually mature male and female Long Evans rats and $\mathrm{BALB} / \mathrm{c}$ mice were used; the animals were kept in a cycle of $12 \mathrm{~h}$ light: $12 \mathrm{~h}$ dark and given water ad libitum and a standard laboratory diet $(G 2+$; King and Co., North Melbourne). This balanced diet consisted of wheat meal, soybean meal, linseed meal, rice pollard, meat meal, molasses, vitamins, minerals, salts, calcium and phosphorus.

\section{Steroid}

RU486 (Mifepristone) was a gift from A. Ulmann (RousselUclaf, Paris).

\section{Baits and diet}

Paraffin wax (Paraplast: melting point $56^{\circ} \mathrm{C}$, Monoject Scientific, St Louis, MO) was first melted in an oven at $65^{\circ} \mathrm{C}$. The required amount of RU486 was added to the melted paraffin which was stirred on a hot plate for $20 \mathrm{~min}$. A mixture of blended cereals was then added to give a ratio of $26 \%$ paraffin: $74 \%$ mixed cereals (wheat meal $29 \%$, corn meal 
$28 \%$, oat meal $28 \%$, canary seed $7 \%$, sugar $7 \%$ and defatted milk powder $1 \%$ ). After mixing well, blue cake and confectionery dye (Queen Fine Foods Pty Ltd, Queensland) was added for the purpose of identification ( $3 \mu \mathrm{l}$ dye: $I \mathrm{~g}$ cerealparaffin mixture). The paraffin mixture was then poured into plastic dishes, $7 \mathrm{~cm}$ square and $1 \mathrm{~cm}$ deep and allowed to set, to produce individual paraffin blocks weighing approximately $35 \mathrm{~g}$. The concentration of RU486 in the blocks was $150 \mathrm{mg}$ $\mathrm{kg}^{-1}$ block. Untreated control paraffin blocks were prepared in the same way but without the addition of steroid.

\section{Treatment groups}

Palatability of RU486 paraffin blocks. Twelve adult female rats were housed individually and vaginal smears were examined for 5 days to assess the normality of their oestrous cycles. They were then weighed and assigned at random to control or treatment groups of six animals. Twelve adult male rats were also weighed and caged singly, and assigned randomly to control or treatment groups of six animals. In addition to the standard laboratory diet, all animals were given either the untreated or treated paraffin blocks for three periods of 6 days, separated by periods of 2 days with no treatment. This 2 day interval was to assess re-acceptability of the bait. One block was suspended inside each cage by a wire. Food intake of the laboratory diet and paraffin blocks was recorded daily throughout the treatment period by weighing the food remaining in the hoppers and weighing the paraffin blocks. Any broken-off pieces of paraffin block in the bottom of the cage were separated from faeces and weighed.

During the treatment periods, vaginal smears were taken daily to determine whether ingestion of RU486 could inhibit ovulation. On day 23, after the last day of treatment, control males and females and treated males and females were paired together in cages with sawdust bedding. Dates of birth and number of offspring were recorded as an index of post-treatment fertility.

An identical experiment was performed with twelve male and twelve female mice.

Antifertility effects of RU486. Eighteen male and eighteen female rats were weighed and assigned at random to a control group or to treatment groups $A$ and $B$, each of six pairs of animals. In addition to the standard laboratory diet, animals in the control and treatment group A were given untreated or treated paraffin blocks daily from the day of pairing for 30 days and then were killed. Their testes, epididymides and ovaries were weighed. The females were examined for pregnancy. The animals in treatment group B were first given the treated blocks for 3 days starting 22 days after pairing. Thereafter, they were given the treated blocks daily for 3 days every 21 days. Throughout the course of the experiment consumption of the paraffin blocks was recorded, together with the dates of birth and number of offspring. On day 109, the male rats were killed by $\mathrm{CO}_{2}$ and their testes and epididymides weighed. On day 115 , the females were killed by $\mathrm{CO}_{2}$, the ovaries weighed, and the number of pregnant females and number of fetuses in a litter were recorded.

A similar trial was carried out in mice, with the exception that from day 82 after the start of treatment, the non-treatment period was reduced from 21 days to 18 days. Male mice were killed by $\mathrm{CO}_{2}$ on day 103 and females on day 109 .

Analysis of data. Results are shown as means \pm SEM throughout. Comparisons between means of control and treatment groups were made using the unpaired $t$ test, unless otherwise indicated. 'Not significant' implies $P>0.05$.

\section{Results}

\section{Palatability of RU486 paraffin blocks}

The treated paraffin blocks were as palatable as untreated control paraffin blocks for both male and female rats in a free-choice feeding system (Fig. 1). The consumption of control and treated blocks was usually higher on the first day of the experiment than on subsequent days. The average consumption of the treated blocks by male rats was $20.7 \mathrm{~g}$ per rat per day, giving an effective consumption of RU486 of $10.8 \mathrm{mg}$ $\mathrm{kg}^{-1}$ body weight day ${ }^{-1}$; for treated female rats, block consumption was $13.1 \mathrm{~g}$ per rat per day, with an RU486 consumption of $11.3 \mathrm{mg} \mathrm{kg}^{-1}$ body weight day ${ }^{-1}$. Animals ate over three times more of the standard laboratory diet on days when the paraffin blocks were not given than on the days when they were available (Table 1), indicating the high palatability of the paraffin blocks. Indeed, both control and treated paraffin blocks were much more palatable than the standard laboratory diet.

The treated paraffin blocks were also just as palatable to mice as the untreated paraffin blocks (Fig. 2). The average consumption of the treated blocks by male mice was $6.6 \pm 0.5 \mathrm{~g}$ per mouse per day, and for female mice it was $5.0 \pm 0.2 \mathrm{~g}$ per mouse per day. Thus the average consumption of RU486 was $37.4 \mathrm{mg} \mathrm{kg}^{-1}$ body weight day ${ }^{-1}$ for the males and $36.4 \mathrm{mg} \mathrm{kg}^{-1}$ body weight day ${ }^{-1}$ for the females. As in the experiments with rats, the mice ate significantly more of the standard laboratory diet on the days when paraffin blocks were unavailable than when the blocks were available (Table 1), indicating the high palatability of the control and treated paraffin blocks.

Before the start of treatment, both control and treated females experienced normal oestrous cycles, as judged by their vaginal smears. During the treatment period, the control female rats continued to have normal oestrous cycles, whereas all the treated female rats showed constant oestrous vaginal smears from day 4 of treatment until its end, including the periods of 2 days with no treatment. At the end of the treatment, all the female rats in both groups gave birth to normal young. Their litter sizes were similar: $8.8 \pm 1.0$ and $9.5 \pm 1.6$ young per litter in the control and treatment groups, respectively. However, the treated females gave birth $35.2 \pm 3.7$ days after being caged with males; this was significantly later than the $26.0 \pm 0.5$ days of the control animals, presumably because it takes some time for ovarian follicular development to return to normal following cessation of treatment.

During the experiment, one female mouse in the control and in the treatment groups died of apparently unrelated causes. At the end of treatment, all the mice gave birth to normal young. The litter sizes, although smaller in the treated group $(5.6 \pm 1.7$ 


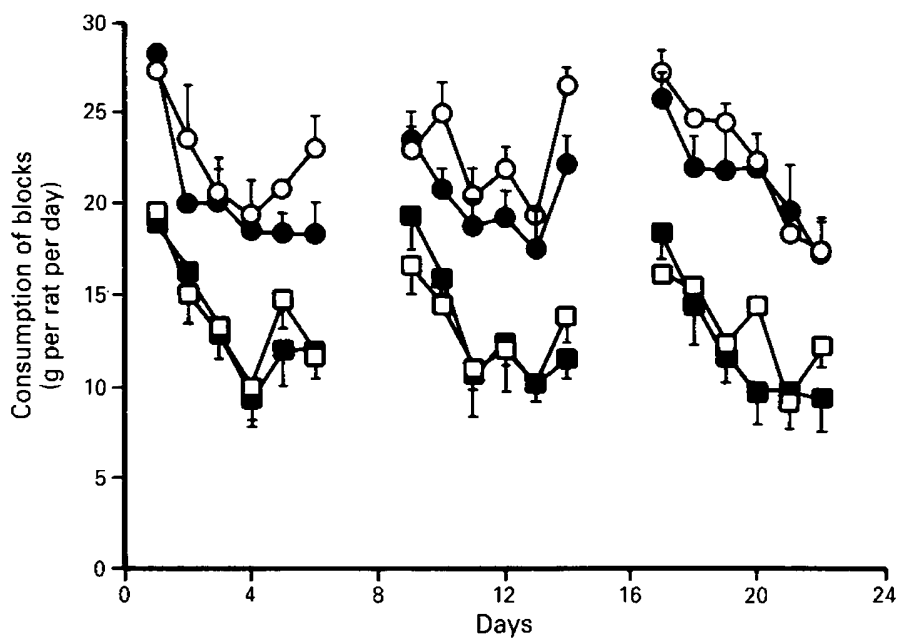

Fig. 1. Daily consumption (mean \pm SEM) of untreated paraffin blocks or paraffin blocks containing $150 \mathrm{mg}$ RU486 $\mathrm{kg}^{-1}$ block by rats in a free-choice feeding trial in the presence of their standard laboratory diet for three periods of 6 days separated by intervals of 2 days with no treatment. (O) control male rats; (O) treated male rats; $(\square)$ control female rats; treated female rats.

Table 1. Consumption of standard laboratory diet depending on whether control or RU486-treated paraffin blocks were available ( $\mathrm{g}$ per animal per day)

\begin{tabular}{lccc}
\hline Animals & Paraffin blocks available & Paraffin blocks not available & $P$ \\
\hline Control male rats & $3.2 \pm 0.4$ & $18.7 \pm 0.8$ & $<0.0001$ \\
Treated male rats & $4.1 \pm 0.3$ & $18.4 \pm 0.5$ & $<0.0001$ \\
Control female rats & $2.8 \pm 0.3$ & $12.2 \pm 0.5$ & $<0.0001$ \\
Treated female rats & $4.0 \pm 0.4$ & $13.0 \pm 1.4$ & $<0.0001$ \\
Control male mice & $0.5 \pm 0.1$ & $3.7 \pm 0.4$ & $<0.0001$ \\
Treated male mice & $0.4 \pm 0.1$ & $3.4 \pm 0.4$ & $<0.0001$ \\
Control female mice & $0.4 \pm 0.1$ & $3.1 \pm 0.3$ & $<0.0001$ \\
Treated female mice & $0.5 \pm 0.1$ & $2.9 \pm 0.4$ & $<0.0001$ \\
\hline
\end{tabular}

young versus $8.0 \pm 1.6$ young), were not significantly different from those of the controls. However, the treated females gave birth $31.2 \pm 2.9$ days after being caged with males; this was somewhat later than the $24.2 \pm 2.4$ days of the controls, although the difference was not statistically significant.

\section{Antifertility effects of RU486}

Continuous ingestion of RU486 in paraffin blocks for a month in a free-choice feeding system resulted in total prevention of conception in rats. None of the treated females in treatment group A was pregnant at the end of one month. In the intermittent feeding protocol, when treatment was withheld for the first 21 days following pairing, four out of the six rats in treatment group B gave birth, but in two of the four litters all of the litter were dead. After this, none of the treated females gave birth, whereas all of the control females gave birth to another three litters (Table 2). Autopsy revealed that five out of the six control female rats were pregnant, whereas none of the treated females in treatment group $B$ was pregnant.

In mice, none of the treated females in treatment group $A$ was pregnant at autopsy at the end of 30 days of continuous exposure to RU486. After intermittent feeding, the controls produced four litters during the treatment period of 102 days (Table 3). One of the treated female mice in group B died during the first labour. Three of the five remaining mice gave birth to live young (Table 3 ). Three mice also produced a second litter, although somewhat later than the controls (Table 3 ). It was therefore decided to reduce the treatment interval from every 21 days to every 18 days. After this, none of the treated animals produced any more young, and at autopsy none of them was pregnant, whereas four of the six controls were pregnant.

There was no significant difference in weights of testes or epididymides between control and treated animals after 30 days of continuous treatment. However, the ovaries of the 


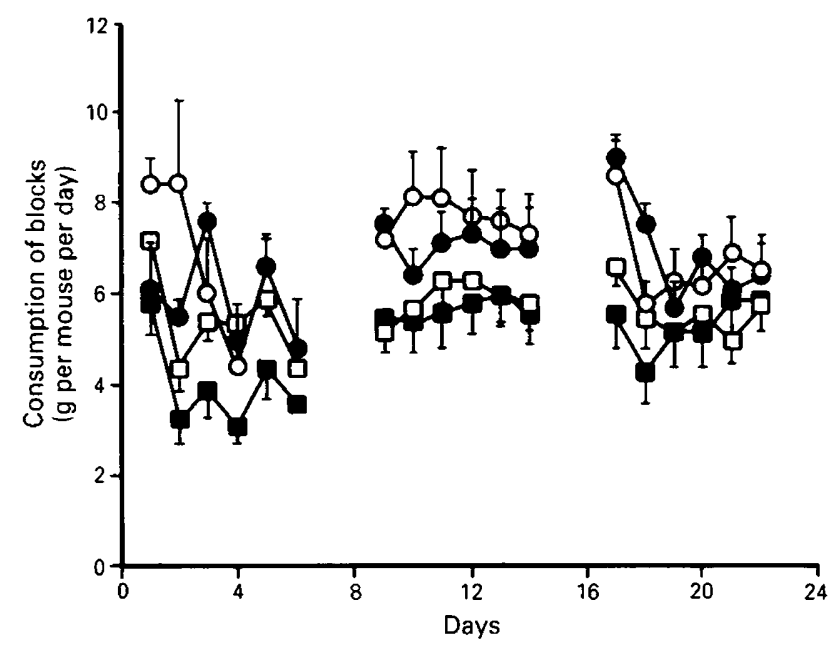

Fig. 2. Daily consumption (mean $\pm S E M$ ) of untreated paraffin blocks or paraffin blocks containing $150 \mathrm{mg} \mathrm{RU} 486 \mathrm{~kg}^{-1}$ block by mice in a free-choice feeding trial in the presence of their standard laboratory diet for three periods of 6 days separated by intervals of 2 days with no treatment. (O) control male mice; ( $O$ ) treated male mice; $(\square)$ control female mice; $(\boldsymbol{\square})$ treated female mice.

treated animals were significantly heavier than those of the controls, owing to the increased amount of luteal tissue. The paired ovarian weight in control rats was $87.7 \pm 9.0 \mathrm{mg}$ versus $120 \pm 8.3 \mathrm{mg}(P<0.01)$ in the treated rats. The ovaries of control mice weighed $11.2 \pm 1.0 \mathrm{mg}$ versus $25.8 \pm 4.6 \mathrm{mg}$ $(P<0.05)$ in the treated mice.

\section{Discussion}

These experiments demonstrate conclusively that RU486, when incorporated into paraffin wax blocks containing an admixture of cereal grains to give a concentration of $150 \mathrm{mg}$ RU486 $\mathrm{kg}^{-1}$ paraffin block, is completely palatable to rats and mice, and is eaten in preference to their standard laboratory diet. At this concentration, rats consumed a daily dose of about $12 \mathrm{mg} \mathrm{RU} 486 \mathrm{~kg}^{-1}$ body weight, and mice $37 \mathrm{mg} \mathrm{kg}^{-1}$. All the treated female rats and mice developed oestrous vaginal smears and their ovaries were significantly heavier because of an increased amount of luteal tissue; testicular weight was unaffected. Philibert et al. (1985) and van der Schoot et al. (1987) also recorded a significant increase in rat ovarian weight following chronic RU486 treatment. In the study reported here, treated paraffin blocks provided intermittently, for 3 days every 21 days to rats, and for 3 days every 18 days to mice, prevented the birth of any live young.

Antigestagens like RU486 therefore have a number of significant advantages over androgens, oestrogens or gestagens for rodent fertility control. Methyltestosterone is relatively unpalatable at the concentration required to induce infertility; ethinyl oestradiol causes complete bait rejection; and Org 5933, a potent orally active gestagen, although completely palatable, has to be fed continuously to inhibit ovulation, and fertility returns rapidly following the cessation of treatment (Gao and Short, 1993b). The complete inhibition of rodent reproduction by the intermittent use of an antigestagen is likely to make this a much more cost-effective way of controlling rodent reproduction. In the accompanying paper (Gao and Short, 1994), we demonstrated that the intermittent

Table 2. Fertility of rats given paraffin blocks containing $150 \mathrm{mg}$ RU486 $\mathrm{kg}^{-1}$ block for 3 days every 21 days

\begin{tabular}{lcccc}
\hline Group & First litter & $\begin{array}{c}\text { Number of rats giving birth and litter size } \\
\text { Second litter }\end{array}$ & Third litter & Fourth litter \\
\hline $\begin{array}{c}\text { Control }(n=6) \\
\text { Litter size }\end{array}$ & 6 & 6 & 6 & 6 \\
$\begin{array}{c}\text { Treated }(n=6) \\
\text { Litter size }\end{array}$ & $11.0 \pm 1.2$ & $9.0 \pm 1.7$ & $10.2 \pm 1.3$ & $10.7 \pm 0.6$ \\
\hline
\end{tabular}

The first treatment started on day 21 after pairing.

Table 3. Fertility of mice given paraffin blocks containing $150 \mathrm{mg}$ RU486 $\mathrm{kg}^{-1}$ block for 3 days every 21 days or 18 days

\begin{tabular}{lcccc}
\hline Group & First litter & $\begin{array}{c}\text { Number of mice giving birth and litter size } \\
\text { Second litter }\end{array}$ & Third litter & Fourth litter \\
\hline $\begin{array}{c}\text { Control }(n=6) \\
\text { Litter size }\end{array}$ & 6 & 6 & 5 & 3 \\
$\begin{array}{c}\text { Treated }(n=6) \\
\text { Litter size }\end{array}$ & $6.5 \pm 0.7$ & $9.5 \pm 1.1$ & $8.2 \pm 1.2$ & $8.3 \pm 0.7$ \\
\hline
\end{tabular}

The first treatment started on day 21 after pairing. After birth of the second litter to the treated animals, the treatment interval was reduced to 18 days. 
administration of RU486 is much more effective in inhibiting the reproduction of wild mice in large outdoor enclosures than is the continuous administration of methyltestosterone.

One major advantage of the antigestagens in comparison to all other steroidal chemosterilants is that they show a degree of species specificity. For example, RU486 does not show highaffinity binding to the endometrial progesterone receptors of chickens, hamsters, cats, horses, wallabies or Australian native cats (Gao and Short, 1993a and unpublished observations). In chickens and hamsters, this lack of binding has been shown to be due to a single amino acid substitution at position 575 in the receptor molecule; if the cysteine of the chicken or hamster is replaced by glycine, RU486 binding and antigestagenic activity is restored (Benhamou et al., 1992). Thus it might be possible to select an antigestagen that was relatively specific for the target species, thereby reducing the problem of secondary effects following accidental ingestion by non-target species.

The primary site of action of RU486 in controlling rodent fertility, especially following intermittent administration, is presumably the uterus. Competitive binding to the uterine progesterone receptor will result in increased uterine contractility and induction of abortion. The fact that all the treated rats and mice in the study reported here showed oestrous vaginal smears is presumably a consequence of the withdrawal of progestagenic influence on the vaginal epithelium.

Although it has been claimed that chronic RU486 administratrion does not block ovulation in rats (Philibert et al., 1985; van der Schoot et al., 1989), it has been shown that RU486 blocks the action of progesterone on the granulosa cells of the Graafian follicles of rats, thereby inhibiting the development of $3 \beta$-hydroxysteroid dehydrogenase activity. This appears to block preovulatory progesterone production and hence the induction of the preovulatory surge of $\mathrm{LH}$ and ovulation (Tanaka et al., 1993). When women were given a continuous low dose of RU486 of 5-10 mg day ${ }^{-1}$, follicular growth was arrested and ovulation inhibited; after the cessation of treatment, follicular maturation resumed, and there was an LH surge followed by ovulation (Croxatto et al., 1993). In the studies reported here, none of the rats or mice on continuous RU486 treatment became pregnant. However, they all conceived and had normal size litters, soon after the cessation of treatment, although there was a delay in conception of 7-9 days compared with the controls. We could not determine whether ovulation was inhibited, but the volume of luteal tissue increased in rats and mice following chronic administration.
In conclusion, it seems that the intermittent use of antigestagens like RU486 holds much promise as a novel way of regulating rodent fertility.

The authors thank A. Ulmann, Roussel-Uclaf for donating the RU486, and to the Grains Research and Development Corporation of Australia for financial support.

\section{References}

Beier S, Kaufmann J and Neef G (1986) Antifertile effects of antigestagens (AG) at various stages of pregnancy in rats Acta Endocrinologica Supplementum 274 8-9

Benhamou B, Garcia T, Lerouge T, Vergezac A, Gofflo D, Bigogne C, Chamboon P and Gronemeyer $H$ (1992) A single amino acid that determines sensitivity of progesterone receptors to RU 486 Science 255 206-209

Chwalisz K and Elger W (1986) Induction of labour with antigestagens in the rat and guinea pig Journal of Steroid Biochemistry 25 (Supplement) 345

Croxatto HB, Salvatierra AM, Croxatto HD and Fuentealba B (1993) Effects of continuous treatment with low dose mifepristone throughout one menstrual cycle Human Reproduction 8 201-207

Gao Y and Short RV (1993a) The control of rodent populations Oxford Reviews of Reproductive Biology 15 265-310

Gao Y and Short RV (1993b) Use of an oestrogen, androgen or gestagen as a potential chemosterilant for control of rat and mouse populations Journal of Reproduction and Fertility 97 39-49

Gao Y and Short RV (1994) Fertility control in wild mice after feeding with RU486 or methyl testosterone Journal of Reproduction and Fertility 101 483-487

Kovacs L, Sas M, Resch BA, Ugocsai G, Swahn ML, Bygdeman M and Rowe PJ (1984) Termination of very early pregnancy by RU 486 , an antigestational compound Contraception $29399-410$

Philibert D, Moguilewsky M, Mary I, Lecaque D, Tournemine C, Secchi J and Deraedt R (1985) Pharmacological profile of RU486 in animals. In The Antiprogestin Steroid RU486 and Human Fertility Control pp 49-68 Eds E Baulieu and SJ Segal. Plenum Press, New York

Tanaka N, Iwamasa J, Matsuura K and Okamura H (1993) Effects of progesterone and anti-progesterone RU486 on ovarian $3 \beta$-hydroxysteroid dehydrogenase activity during ovulation in the gonadotrophin-primed immature rat journal of Reproduction and Fertility 97 167-172

Ulmann A, Teutsch G and Philibert D (1990) RU 486 Scientific American 262 18-24

van der Schoot P, Bakker GH and Klijn JGM (1987) Effect of progesterone antagonist RU486 on ovarian activity in the rat Endocrinology 121 13751382

van der Schoot P, Uilenbroek JTJ and Slappendel EJ (1989) Failure of two progesterone antagonists, mifepristone and onapristone to affect luteal activity in lactating rats Journal of Reproduction and Fertility 87 593-601

Van Look PFA and Bygdeman M (1989) Antiprogestational steroids: a new dimension in human fertility regulation Oxford Reviews of Reproductive Biology 11 1-60 